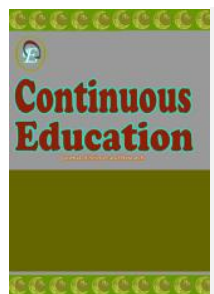

\title{
Meningkatkan Keterampilan Mengajar Guru Bidang Studi Agama Melalui Pembimbingan Dan Praktek Mengajar
}

\author{
Alhafif Syahputra \\ Kementerian Agama Kota Pematangsiantar
}

Corresponding Author: $\otimes$ indrie.mdn@gmail.com

\section{ABSTRACT}

Teachers in the field of Religious Studies have poor teaching skills. Teachers are always given instruction in the traditional lecture format,

ARTICLE INFO

Article history:

Received

25 November 2021

Revised

29 November 2021

Accepted

01 Desember 2021

Keywords

How to cite which is not accompanied by any teaching techniques. Through mentoring and teaching methods, this project intends to strengthen the teaching skills of Religious Studies teachers at MTsN Pematangsiantar. This research uses a school action research approach, research was undertaken at MTsN Pematangsiantar with a total of 15 teachers involved, and it is a school action research project. The findings revealed that 1) the mean value of teacher teaching skills increased significantly, 2) the mean value of teacher teaching skills in Pre-cycle was 112,00, and the mean value of teacher teaching skills in Cycle I increased to 220,47, and 3) the mean value of teacher teaching skills in Cycle II increased to 253,40.

Teacher, Religion, Teaching Practice

Alhafif Syahputra (2021). Meningkatkan Keterampilan Mengajar Guru Bidang Studi Agama Melalui Pembimbingan Dan Praktek Mengajar. Journal Continuous Education, 2(3). 1-15. 10.51178/ce.v2i3.312

\section{PENDAHULUAN}

Pendidikan merupakan upaya pendewasaan anak didik yang dilakukan orang dewasa yang sadar dan bertanggungjawab. Pendewasaan anak didik yang dilakukan menyangkut bidang fisik dan mental (Zaini \& Syafaruddin, 2020). Dewasa secara fisik artinya anak didik tumbuh dan berkembang sesuai fase-fase perkembangannya secara biologis. Sedangkan dewasa secara mental berarti anak didik mengalami pertumbuhan mental secara normal sesuai dengan fase-fase perkembangannya secar psikologis, sehingga terbina individu yang matang baik fisik maupun psikis. Mengingat begitu pentingnya peranan pendidikan maka alangkah wajarnya bila berbagai faktor pendukung terhadap pendidikan mendapat perhatian yang lebih serius (Kristiawan \& Rahmat, 2018). Diantara faktor pendukung tersebut terdapat sarana dan fasilitas yang merupakan penunjang terselenggaranya pendidikan secara wajar dan berkesinambungan. Terselenggaranya pendidikan secara wajar 
Journal Continuous Education

Volume 2, Issue 3, November 2021

Page 1-15

menitikberatkan perhatian akan aktivitas pendidikan yang dilakukan harus dapat membangkitkan seluruh potensi yang ada pada anak didik sehingga berbagai kecerdasan yang saat ini telah diakui dimiliki oleh manusia dapat dimunculkan. Sedangkan pendidikan dilaksanakan secara berkesinambungan menitik beratkan pada keberlangsungan pendidikan sampai jenjang yang diharapkan dan berlangsung dari generasi ke generasi berikutnya (Bafadal, 2008).

Dalam proses pendidikan peranan guru sangat penting dan begitu menentukan. Proses pendidikan tidak akan berlangsung tanpa adanya guru. Keberhasilan pendidikan dari segi infut, proses maupun outputnya akan sangat banyak ditentukan dari kompetens, dedikasi maupun kredibilitas para guru dalam mengelola dan melaksanakan proses pendidikan. (Amri et al., 2019) Mengatakan peranan guru adalah terciptanya tingkah laku yang saling berkaitan yang dilakukan dalam suatu situasi tertentu serta berhubungan dengan kemajuan perubahan tingkah laku dan perkembangan siswa yang menjadi tujuannya. Seorang guru yang baik adalah guru yang mampu memberikan ilmu yang dimilikinya secara maksimal kepada anak didik. Proses pemberian ilmu akan dapat maksimal diserap anak didik diperlukan kepiawaian dalam strategi dan metode serta berbagai keterampilan menggunakan berbagai sumber belajar. Kepiawaian guru dalam memberikan pengalaman dan ilmu yang dimilikinya disebut dengan kompetensi guru. Kemudian lebih dari itu, seorang guru tidak hanya dituntut piawai dalam mengolah kelas menjadi tempat munculnya berbagai potensi anak, tetapi juga harus mampu mengembangkan kemampuan yang telah dimilikinya tersebut. Setelah dikembangkannya, aktivitas sang guru yang dituntut berikutnya adalah memasyarakatkan kemampuan tersebut kepada masyarakat luas. Dengan demikian kemampuan yang dimilikinya tidak hanya bermanfaat untuk muridmuridnya saja di ruang belajar, melainkan juga harus disosialisasikan kepada khalayak.

Untuk menjadi sosok individu sebagaimana yang diharapkan itu, maka guru sebaiknya senantiasa meningkatkan kualitas dirinya secara profesional. Jika dikonotasikan dengan profesional bukanlah hanya menguasai bidang ajarnya saja, akan tetapi harus mampu menggabungkannya keahliannya dengan berbagai bidang lain, sehingga tidak menimbulkan kemampuan yang monoton dan melulu hanya dalam bidang ilmu yang diajarkannya. Penggabungan berbagai kemampuan dari bidang lain akan memunculkan penyajian seorang guru menjadi penyajian yang menarik dan dinamis. Kemampuan profesional guru harus ditingkatkan baik oleh guru itu sendiri, maupun oleh pihak-pihak lain yang terkait serta memiliki hubungan, baik 
Journal Continuous Education

Volume 2, Issue 3, November 2021

Page 1-15

langsung maupun tidak langsung. (Sudarwan, 2012) Menyatakan guru memiliki banyak tugas baik yang terikat oleh dinas maupun di luar dalam bentuk pengabdian. Apabila dikelompokkan terdapat dua jenis tugas guru yakni tugas dalam bidang profesi tugas kemanusiaan dan dalam bidang kemasyarakatan. Tugas guru sebagai profesi kemanusiaan meliputi mendidik, mengajar dan melatih. Mendidik berarti meneruskan dan mengembangkan ilmu pengetahuan dan teknologi. Sedangkan melatih berarti mengembangkan keterampilan-keterampilan pada siswa.

Guru bidang studi Agama adalah guru yang mengajar mata pelajaran Alquran Hadits, Aqidah Akhlak Fiqih dan Sejarah Kebudayaan Islam (SKI). Di Madrasah Tsanawiyah Negeri (MTsN) Pematangsiantar guru bidang studi Agama berjumlah 15 orang. Dari 15 orang ini yang berstatus Pegawai Negeri Sipil (PNS) berjumlah 7 orang dan yang berstuatus guru bukan Pegawai Negeri Sipil (GBPNS) berjumlah 8 orang. Sebelum dilakukan penelitian ini guru bidang studi Agama yang mengajar di MTsN Pematangsiantar seluruhnya telah dilakukan penilaian tentang keterampilan mengajarnya oleh penulis bekerja sama dengan Sekolah Tinggi Agama Islam (STAI) Samora Pematangsiantar. Dengan menggunakan instrumen keterampilan mengajar dari Sekolah Tinggi Agama Islam (STAI) Samora Pematangsiantar, yang instrumen ini digunakan juga untuk menilai kemampuan mengajar mahasiswa secara praktis pada PPL (praktek pengenalan lapangan). Instrumen keterampilan mengajar ini disusun sebanyak 55 butir pertanyaan menggunakan teknik semantic differensial (the semantic differential technique). Teknik semantic differensial ini merupakan teknik dengan bentuk skala nilai yang memiliki dua kutub sifat yang berbeda (Bloom, dkk. 1971). Pada setiap pertanyaan di buat skala nilai yang terdiri dari angka 1,2,3,4 dan 5 yang akan dipilih oleh penilai keterampilan mengajar. Untuk angka 1 dan 2 termasuk kategori rendah dan angka 4 dan 5 termasuk kategori tinggi sedangkan angka 3 termasuk kategori sedang. Dari 15 orang guru bidang studi Agama yang dinilai diperoleh hasilnya sebagai berikut :

Tabel 1. Keterampilan Mengajar Guru Bidang Studi Agama MTsN Pematangsiantar

\begin{tabular}{|c|c|c|}
\hline $\begin{array}{c}\text { Nilai Rata-rata } \\
\text { Keterampilan Mengajar }\end{array}$ & $\begin{array}{c}\text { Nilai Rata-rata } \\
\text { Penggunaan Model } \\
\text { Pembelajaran }\end{array}$ & $\begin{array}{c}\text { Nilai Rata-rata Pemanfaatan } \\
\text { Sumber Belajar/Media } \\
\text { Pembelajaran }\end{array}$ \\
\hline 112 & 60 & 5,9 \\
\hline
\end{tabular}

Nilai rata-rata yang dari keterampilan mengajar guru Agama yang diperoleh adalah 112. Angka ini tergolong rendah jika dihitung angka maksimal yang mungkin diperoleh seorang guru dari 55 butir instrumen 
Journal Continuous Education

Volume 2, Issue 3, November 2021

Page 1-15

penilaian adalah sebesar 275. Angka ini diperoleh dari 55 dikali dengan 5 sebagai skor maksimal. Sedangkan dari penilaian oleh pengawas dan pihak Sekolah Tinggi Agama Islam (STAI) Samora Pematangsiantar diperoleh angka 112. Berarti angka yang dipilih oleh penilai dominan adalah 1 dan 2 pada setiap pertanyaan. Tidak berbeda dengan rata-rata penggunaan model pembelajaran (instrumen 3 sampai dengan 33) angka rata-rata yang diperoleh sebesar 60, yang berarti juga yang diisi oleh penilai pada saat penilaian berkisar pada angka 1 dan 2. Kemudian nilai rata-rata pemanfaatan sumber belajar/media pembelajaran (instrumen butir 48 sampai dengan 50) adalah sebesar 5,9. Juga angka tergolong rendah sebab penilaian dominan juga memilih angka penilaian berkisar pada angka 1 dan 2. Dari hasil keseluruhan penilaian awal yang telah dilakukan dapat disimpulkan bahwa keterampilan mengajar guru bidang studi Agama MTsN Pematangsiantar tergolong rendah. Berdasarkan data tersebut penulis tertarik untuk melakukan penelitian tentang upaya yang dilakukan untuk meningkatkan keterampilan mengajar guru bidang studi Agama MTsN Pematangsiantar dengan judul penelitian "Meningkatkan Keterampilan Mengajar Guru Bidang Studi Agama Melalui Pembimbingan Dan Praktek Mengajar".

\section{METODE PENELITIAN}

Penelitian ini adalah penelitian tindakan sekolah (PTS) yang dimaksudkan untuk mencari solusi dari permasalahan rendahnya keterampilan mengajar guru bidang studi Agama yang mengajar di MTsN Pematangsiantar. Penelitian ini berlangsung selama 3 bulan dengan melibatkan 15 orang guru bidang studi Agama yang mengajar di MTsN Pematangsiantar. Sedangkan jenis penelitian ini termasuk kedalam penelitian lapangan (field research) yang bersifat deskriptif kualitatif yang bertujuan untuk mengetahui pengaruh perlakuan (pembimbingan dan praktek mengajar) terhadap peningkatan keterampilan mengajar guru bidang studi Agama MTsN Pematangsiantar. Dari permasalahan yang ada yaitu rendahnya keterampilan mengajar guru bidang studi Agama yang mengajar di MTsN Pematangsiantar, Kemudian diberikan tindakan atau perlakuan yakni pembimbingan dan praktek mengajar terhadap guru lalu diharapkan dapat meningkatkan keterampilan mengajar guru bidang studi Agama yang mengajar di MTsN Pematangsiantar. Menurut (Lexy Moleong, 2014; Sugiyono, 2020) hakekat penelitian kualitatif adalah mengamati orang dalam lingkungan hidupnya berinteraksi dengan mereka, berusaha memahami bahasa dan tafsiran mereka tentang dunia sekitar, mendekati atau berinteraksi dengan orang yang berhubungan dengan fokus penelitian dengan tujuan mencoba memahami, menggali pandangan atau pengalaman mereka 
Journal Continuous Education

Volume 2, Issue 3, November 2021

Page 1-15

untuk mendapatkan imformasi atau data yang diperlukan. Sedangkan Bogdan dan Taylor dalam (Darwamawan, 2013) menjelaskan bahwa metode penelitian kualitatif merupakan prosedur penelitian yang menghasilkan data deskriptif berupa kata-kata tertulis atau lisan dari orang-orang dan perilaku yang dapat diamati. Kemudian (Sugiyono, 2016) Mengemukakan bahwa karakteristik dari penelitian kualitatif adalah (1) alamiah, (2) data bersifat deskriptif bukan angka, (3) analisa data dengan induktif dan (4) makna sangat penting dalam penelitian kualitatif. Oleh sebab itu dalam penelitian kualitatif seorang peneliti berbicara langsung dan berinteraksi selama beberapa minggu atau bulan untuk mempelajari kebiasaan, perilaku serta perubahan perilaku dari orang yang diteliti. Dalam pelaksanaan penelitian ini dibagi tiga tahap yaitu tahap perencanaan (plan), tahap pelaksanaan (do) dan tahap refleksi (see). Pada tahap perencanaan (plan) yang dilakukan adalah mengidentifikasi masalah kemudian menganalisis kebutuhan serta merumuskan alternatif pemecahan masalah. Mengidentifikasi masalah dilakukan dengan kembali mengumpulkan data hasil penilaian keterampilan mengajar guru bidang studi Agama berdasarkan penilaian yang telah dilakukan dosen STAI Samora Pematangsiantar. Kemudian mendata ulang guru bidang studi Agama MTsN Pematangsiantar lalu menyusun materi bimbingan dan prakteknya kemudian menentukan pemateri dari luar pengawas yang direncanakan dari STAI Samora Pematangsiantar dan dari Lembaga Penjamin Mutu Pendidikan (LPMP) Medan dan lokasi bimbingan di MTsN Pematangsiantar. Kemudian tahap pelaksanaan (do) dilakukan dengan menyusun materi bimbingan sesuai dengan analisa kebutuhan para guru bidang studi Agama MTsN Pematangsiantar. Dan pada tahap pelaksanaan penelitian dibagi menjadi 2 siklus sebagai berikut :

Tabel 2. Pelaksanaan Siklus Penelitian

\begin{tabular}{|c|l|l|c|}
\hline Siklus & No & \multicolumn{1}{|c|}{ Judul Materi Bimbingan } & $\begin{array}{c}\text { Pelaksana/Penyaji Materi } \\
\text { Bimbingan }\end{array}$ \\
\hline $\begin{array}{c}\text { Pra } \\
\text { Siklus }\end{array}$ & 1 & $\begin{array}{l}\text { Melakukan Penilaian Keterampilan } \\
\text { Mengajar Guru (Pengumpulan Data Awal) }\end{array}$ & STAI Samora dan Pengawas \\
\hline I & 1 & $\begin{array}{l}\text { Keterampilan Membuka Pelajaran dan } \\
\text { Pendekatan Saintifik }\end{array}$ & Pengawas \\
\hline & 2 & Penilaian Autentik dan Umpan Balik & Pengawas \\
\hline & 3 & $\begin{array}{l}\text { Praktek Mengajar Guru Fiqih, Al-quran } \\
\text { Hadits, Aqidah Akhlak dan SKI }\end{array}$ & Pengawas \\
\hline & & Penilaian Keterampilan Mengajar ke Lokal & STAI Samora dan Pengawas \\
\hline II & 1 & Model-model Pembelajaran & LPMP Medan \\
\hline & 2 & Model Pembelajaran Agama & $\begin{array}{l}\text { Praktek Mengajar Guru Fiqih, Al-quran } \\
\text { Hadits, Aqidah Akhlak dan SKI }\end{array}$ \\
\hline & 3 & Penilaian Keterampilan Mengajar ke Lokal & STAI Samora dan Pengawas \\
\hline
\end{tabular}


Journal Continuous Education

Volume 2, Issue 3, November 2021

Page 1-15

Dengan demikian penilaian keterampilan mengajar ke lokal saat guru menyajikan materi pembelajaran dilakukan setiap siklus. Nilai keterampilan mengajar guru yang diperoleh pada siklus 1 dibandingkan dengan nilai keterampilan mengajar yang diperoleh pada siklus II. Kemudian dilakukan analisa tentang perlakuan bimbingan yang telah diberikan pada guru bidang studi Agama, apakah berdampak positip (meningkat) terhadap keterampilan mengajar guru atau berdampak negatif (menurun) terhadap keterampilan mengajar guru. Analisa data dilakukan dengan membandingkan nilai rata-rata (skor rata-rata) keterampilan mengajar para guru bidang studi Agama pada prasiklus, siklus I dan siklus II. Kemudian membandingkan ketiga data dengan uji t melalui perhitungan dengan program SPSS 23 (Santoso, S. (2016) untuk membuktikan signifikansi perbedaan datanya. Dan pada tahap refleksi (see) dilakukan revewer (peninjauan ulang) tentang keseluruhan pembimbingan dan praktek mengajar yang telah dilaksanakan. Pada tahap refleksi juga dilakukan evaluasi terhadap kegiatan pembimbingan dan praktek mengajar. Berdasarkan refleksi ini diambil kesimpulan untuk dilakukan tindak lanjut setelah proses pembimbingan dan praktek mengajar terhadap para guru bidang studi Agama MTsN Pematangsiantar.

\section{HASIL PENELITIAN DAN PEMBAHASAN}

Deskripsi Data Hasil Penelitian (Data Keterampilan Mengajar Setiap Siklus)

Tabel 3. Perhitungan Uji t Skor Pra Siklus dengan Siklus I

Paired Samples Test

\begin{tabular}{|c|c|c|c|c|c|c|c|c|}
\hline & \multicolumn{5}{|c|}{ Paired Differences } & \multirow[b]{3}{*}{$\mathrm{t}$} & \multirow[b]{3}{*}{$\mathrm{df}$} & \multirow{3}{*}{$\begin{array}{l}\text { Sig. (2- } \\
\text { tailed) }\end{array}$} \\
\hline & \multirow[b]{2}{*}{ Mean } & \multirow{2}{*}{$\begin{array}{c}\text { Std. } \\
\text { Deviati } \\
\text { on }\end{array}$} & \multirow{2}{*}{$\begin{array}{l}\text { Std. } \\
\text { Error } \\
\text { Mean }\end{array}$} & \multicolumn{2}{|c|}{$\begin{array}{l}\text { 95\% Confidence } \\
\text { Interval of the } \\
\text { Difference }\end{array}$} & & & \\
\hline & & & & Lower & Upper & & & \\
\hline $\begin{aligned} & \text { Pair } 1 \text { Keterampilan } \\
& \text { Mengajar Pra Siklus - } \\
& \text { Ketrampilan } \\
& \text { Mengajar Siklus I }\end{aligned}$ & $-108,467$ & 834 & ,215 & $-108,928$ & $-108,005$ & $-503,820$ & 14 & ,000 \\
\hline
\end{tabular}

Berdasarkan aturan untuk uji dua sisi (uji beda) jika nilai probabilitas dibagi $2>0,025$ maka kedua sampel yang diteliti tidak berbeda, akan tetapi jika nilai probabilitas dibagi $2<0,025$ maka kedua sampel yang diteliti berbeda secara signifikan. Dari tabel terlihat nilai probabilitas (signifikansi) 0,000. Kemudian jika angka probabilitas dibagi 2 maka diperoleh 0,000:2 $=0.000$. Karena 0,000 berada di bawah 0,025 maka dapat disimpulkan bahwa nilai keterampilan mengajar guru Pra Siklus berbeda secara signifikan dengan keterampilan mengajar guru Siklus I. Kemudian untuk uji beda yang kedua 
Journal Continuous Education

Volume 2, Issue 3, November 2021

Page 1-15

yaitu uji t antara skor keterampilan mengajar Siklus I dengan skor keterampilan mengajar Siklus II diperoleh hasil sebagai berikut :

Tabel 4. Perhitungan Uji t Skor Siklus I dengan Siklus II

Paired Samples Test

\begin{tabular}{|c|c|c|c|c|c|c|c|c|}
\hline & \multicolumn{5}{|c|}{ Paired Differences } & \multirow[b]{3}{*}{$\mathrm{t}$} & \multirow[b]{3}{*}{$\mathrm{df}$} & \multirow{3}{*}{$\begin{array}{l}\text { Sig. (2- } \\
\text { tailed) }\end{array}$} \\
\hline & \multirow[b]{2}{*}{ Mean } & \multirow{2}{*}{$\begin{array}{c}\text { Std. } \\
\text { Deviati } \\
\text { on }\end{array}$} & \multirow{2}{*}{$\begin{array}{l}\text { Std. } \\
\text { Error } \\
\text { Mean }\end{array}$} & \multicolumn{2}{|c|}{$\begin{array}{l}\text { 95\% Confidence } \\
\text { Interval of the } \\
\text { Difference }\end{array}$} & & & \\
\hline & & & & Lower & Upper & & & \\
\hline $\begin{array}{l}\text { Pair } 1 \text { Keterampilan Mengajar } \\
\text { Siklus I - Keterampilan } \\
\text { Mengajar Siklus II }\end{array}$ & $-32,933$ & 1,710 & ,441 & $-33,880$ & $-31,986$ & $-74,594$ & 14 & ,000 \\
\hline
\end{tabular}

Dari tabel terlihat nilai probabilitas (signifikansi) 0,000. Jika angka probabilitas ini dibagi 2 maka diperoleh 0,000:2 =0.000. Karena 0,000 berada di bawah 0,025 maka dapat disimpulkan bahwa nilai keterampilan mengajar guru pada Siklus I berbeda secara signifikan dengan keterampilan mengajar guru Siklus II. Setelah dilakukan uji beda dengan uji t ternyata skor keterampilan mengajar guru berbeda secara signifikan antara skor keterampilan mengajar pada Pra Siklus dengan skor keterampilan mengajar guru pada Siklus I. Kemudian skor keterampilan mengajar guru pada Siklus I berbeda secara signifikan dengan skor keterampilan mengajar guru pada Siklus II. Hal ini terjadi tentunya pengaruh pembimbingan dan praktek mengajar yang dilakukan terhadap para guru bidang studi Agama MTsN Pematangsiantar. Dengan diberikan pembimbingan dan praktek mengajar ternyata mampu meningkatkan keterampilan mengajar mereka menjadi lebih baik.

\section{Refleksi}

Keterampilan mengajar guru sebelum diadakan bimbingan dan praktek mengajar (Pra Siklus) memiliki nilai rata-rata (mean) sebesar 112,00. Nilai minimumnya 110 dan nilai maksimumnya 115. Angka-angka yang diperoleh ini tergolong rendah jika dibandingkan dengan nilai maksimal yang mungkin diperoleh guru yaitu sebesar 275. Dari hasil penilaian awal ini berarti guru bidang studi Agama mengajar dengan menggunakan cara konvensional, dominan dengan metode ceramah tanpa menggunakan pendekatan saintifik, penilaian autentik serta tanpa menggunakan model pembelajaran. Sepertinya tugas mengajar hanya dilaksanakan untuk sekedar melepaskan kewajiban tanpa berpikir tentang out come (hasil) bagi anak didik. Kemudian bimbingan tentang keterampilan mengajar diberikan disertai dengan praktek mengajar (Siklus I) nilai rata-rata (mean) skor keterampilan mengajarnya mengalami peningkatan menjadi 220,47 dengan nilai minimum 218 dan nilai maksimum 223. Jika dibandingkan nilai mean pada Pra Siklus dengan Siklus I terjadi 
Journal Continuous Education

Volume 2, Issue 3, November 2021

Page 1-15

peningkatan nilai yang signifikan. Hal ini diakibatkan oleh bimbingan yang diberikan kepada para guru baik yang bersifat teoretis maupun praktis (praktek mengajar). Dengan bimbingan guru melakukan pembelajaran sesuai dengan tahapan-tahapan pada pendekatan saintifik dan melakukan penilaian autentik sehingga nilai keterampilan mengajarnya mengalami peningkatan. Kemudian ketika pengetahuan dan keterampilan menggunakan model pembelajaran diberikan pada guru (Siklus II) mean keterampilan mengajarnya juga mengalami kenaikan yang signifikan. Dari hasil uji beda yang dilakukan dengan uji $\mathrm{t}$ diperoleh signifikansi 0,000 yang berada jauh di bawah 0,025, artinya mean nilai antara Siklus I dengan Siklus II berbeda secara signifikan atau meningkat secara valid dan meyakinkan. Dengan demikian dapat disimpulkan bahwa mengajar dengan menggunakan langkah-langkah pendekatan saintifik dan penilaian autentik disertai penerapan model pembelajaran dapat meningkatkan keterampilan mengajar guru bidang studi Agama MTsN Pematangsiantar. Jika keterampilan mengajar para guru meningkat maka pada gilirannya hasil belajar siswa juga akan meningkat.

\section{Pembahasan Hasil Penelitian}

Hasil akhir penelitian bahwa terjadi peningkatan keterampilan mengajar guru bidang studi Agama yang mengajar pada MTsN Pematangsiantar setelah dilakukan pembimbingan dan praktek mengajar. Pembimbingan yang dilakukan yakni pemberian materi tentang keterampilan memulai pembelajaran, menyampaikan materi pembelajaran dengan pendekatan saintifik, melakukan evaluasi dengan penilaian autentik dan keterampilan melakukan umpan balik. Kemudian pembimbingan juga dilakukan dengan memberikan pengetahuan dan keterampilan menggunakan model-model pembelajaran terutama model-model pembelajaran yang sangat dianjurkan dalam bidang studi Agama. Dan juga dilakukan praktek mengajar oleh guruguru bidang studi Agama untuk memantapkan keterampilan mengajar mereka. Hal ini yang disebutkan dalam teori pendidikan dengan kompetensi pedagogik. Kompetensi pedagogik adalah kemampuan seorang guru dalam mengelola proses pembelajaran siswa. Dengan meningkatnya kompetensi pedagogik seorang guru maka kemampuannya dalam mengelola proses pembelajaran semakin meningkat. Secara lebih jelas Janawi (2012: 35) menjelaskan bahwa kompetensi pedagogik meliputi : 1) Pemahaman wawasan atau landasan kependidikan, 2) Pemahaman terhadap siswa secara psikis dan biologis, 3) Pengembangan kurikulum atau silabus, 4) Pelaksanaan pembelajaran yang mendidik dan dialogis, 5) Pengembangan siswa untuk mengaktualisasikan berbagai potensi yang dimilikinya, dan 6) Evaluasi hasil 
Journal Continuous Education

Volume 2, Issue 3, November 2021

Page 1-15

belajar. Memberikan bimbingan dan pembinaan terhadap kompetensi mengajar seorang guru berarti meningkatkan keenam faktor yang termasuk ranah kompetensi pedagogik tersebut. Oleh karena itu jika ingin meningkatkan keterampilan mengajar seorang guru maka ranah kompetensi pedagogik ini harus tergarap dengan baik dan optimal. Hal ini sejalan dengan hasil penelitian (Ekasari, 2015) bahwa kompetensi pedagogik berpengaruh terhadap kemampuan guru dalam mengelola pembelajaran. Guru dengan nilai kompetensi pedagogik tergolong baik, maka kemampuan guru dalam mengelola pembelajaran juga tergolong baik. Sebaliknya jika nilai kompetensi pedagogik tergolong cukup, maka kemampuan guru dalam mengelola pembelajaran juga akan tergolong cukup. Kemudian temuan penelitian bahwa pembimbingan yang diberikan terhadap guru dapat meningkatkan mutu mereka mengajar hal ini sesuai dengan hasil penelitian (Wardhana, 2016) yang meneliti tentang pengaruh Kepemimpinan Kepala Sekolah, Profesionalisme dan Pelatihan Guru Terhadap Implementasi Kurikulum 2013 SMKN Yogyakarta, salah satu hasil penelitiannya adalah bahwa pelatihan guru mempunyai pengaruh positif yang signifikan terhadap implementasi kurikulum 2013 di SMK Negeri Kota Yogyakarta. Lalu hasil penelitian (Mustofa, 2018) yang menyatakan bahwa terkait dengan Pelatihan Multimedia Pembelajaran Interaktif (Lectora Inspire) dapat disimpulkan bahwasanya Pelatihan Multimedia Pembelajaran Interaktif (Lectora Inspire) efektif digunakan sebagai program peningkatan kompetensi profesional calon guru PAI Fakultas Ilmu Tarbiyah dan Keguruan UIN Sunan Kalijaga Yogyakarta.

Kemudian keterampilan mengajar berkaitan dengan bagaimana mengelola suatu pembelajaran dengan baik sehingga dapat meningkatkan hasil belajar siswa. Dalam pembimbingan diberikan materi tentang bagaimana cara yang baik dalam memulai proses pembelajaran, menyampaikan materi dan melakukan evaluasi. Dengan diberikannya pengetahuan yang baik kepada guru maka wawasan mereka tentang pengelolaan pembelajarn meningkat. Dengan meningkatnya wawasan mereka maka pada gilirannya akan meningkatkan keterampilan mengajarnya. Hal ini sesuai dengan yang dijelaskan oleh (Zaini, 2019) yang menyatakan bahwa mengajar yang paling tepat didefenisikan sebagai suatu pengelolaan pembelajaran. Kemudian (Wina Sanjaya, 2007) mengemukakan tiga macam tentang pengertian atau defenisi mengajar, yaitu : (1) mengajar adalah menyampaikan pengetahuan kepada anak, (2) mengajar adalah menyampaikan kebudayaan kepada anak, dan (3) mengajar adalah mengenalkan anak kepada lingkungan sekitar sehingga anak dapat beraktivitas dan mengorganisasi serta menghubungkan sehingga terjadi suatu proses kegiatan belajar-mengajar. Dengan meningkatkan kemampuan 
Journal Continuous Education

Volume 2, Issue 3, November 2021

Page 1-15

mengelola pembelajaran sebagaimana yang dijelaskan Mursell maka keterampilan mengajar akan meningkat dan perubahan seorang anak kearah yang lebih baik akan dapat dilakukan sebagaimana dijelaskan oleh Sanjaya. Kemudian juga hal ini juga sesuai dengan yang dijelaskan Roger (1987: 14) bahwa kompetensi kemampuan guru dikelompokkan ke dalam tiga kelompok yaitu : (1) kemampuan merencanakan pengajaran, (2) kemampuan melaksanakan pengajaran, (3) kemampuan dalam mengevaluasi pengajaran. Dan ketiga kelompok kompetensi tersebut saling berhubungan erat satu dengan lainnya dalam mencapai efektivitas dan efesiensi pengajaran. Dengan meningkatkan pengetahuan dan keterampilan kelompok kompetensi ini maka akan meningkatkan keterampilan mengajar guru. Juga temuan penelitian ini sesuai dengan (Piet, 2009) yang menyatakan bahwa keterampilan mengajar guru meliputi (1) keterampilan memulai pelajaran (2) keterampilan menjelaskan (3) keterampilan bertanya dasar dan lanjut (4) keterampilan dalam memberi penguatan (5) keterampilan mengadakan variasi (6) keterampilan membimbing diskusi (7) keterampilan mengelola kelas dan (8) keterampilan mengakhiri pelajaran. Juga hasil ini sesuai dengan penelitian (Sholikhah et al., 2019) yang menyatakan bahwa pembekalan pengetahuan kepada para pendidik merupakan salah satu upaya peningkatan kompetensi guru dalam mengelola pembelajaran. Dengan berbekal pengetahuan itulah guru dapat mengembangkan potensi anak didik. Pelatihan yang dibutuhkan untuk mengembangkan potensi anak didik tersebut tercakup dalam materi yang disampaikan tim pengabdi (pemateri).

Kemudian dari hasil penelitian diperoleh bahwa bimbingan tentang pengetahuan dan keterampilan menggunakan model pembelajaran juga mempengaruhi keterampilan mengajar para guru. Dengan meningkatnya pengetahuan dan keterampilan para guru menggunakan model pembelajaran, menyebabkan keterampilan mengajarnya meningkat. Hal ini terjadi karena model pembelajaran pada hakikatnya berisi pedoman-pedoman yang harus diikuti guru dan juga siswa agar materi pelajaran yang disajikan guru dapat dikuasai siswa secara optimal. Penguasaan optimal siswa akan materi pelajaran yang menjadi orientasi dari penerapan model pembelajaran. Hal ini sesuai dengan yang dikatakan oleh (Ananda \& Abdillah, 2018) bahwa model pembelajaran memiliki : 1) sintaks (fase pembelajaran) ; 2) sistem sosial ; 3) prinsip reaksi ; 4) sistem pendukung ; dan 5) dampak. Sintaks adalah tahapan dalam mengimplementasi model dalam kegiatan pembelajaran. Sintaks menunjukkan kegiatan apa saja yang perlu dilakukan oleh guru dan peserta didik mulai dari awal pembelajaran sampai akhir. Sistem sosial menggambarkan peran dan hubungan antara guru dan peserta didik dalam 
Journal Continuous Education

Volume 2, Issue 3, November 2021

Page 1-15

aktivitas pembelajaran. Prinsip reaksi merupakan imformasi dari guru untuk merespons dan menghargai apa yang dilakukan oleh peserta didik. Sementara sistem pendukung mendeskripsikan kondisi pendukung yang dibutuhkan untuk mengimplementasikan model pembelajaran. Sebuah model pembelajaran juga memiliki efek atau dampak instruksional dan pengiring (nurturant effect). Dampak instruksional merupakan dampak langsung yang dihasilkan dari materi dan keterampilan berdasarkan aktivitas yang dilakukan. Sedangkan dampak pengiring merupakan dampak tidak langsung yang dihasilkan akibat interaksi dengan lingkungan belajar. Dari hal ini dapat dilihat betapa pentingnya kemampuan dan keterampilan guru dalam menerapkan banyak model pembelajaran. Sebab dengan diberikan pembinaan tentang penerapan model pembelajaran kemampuan guru (keterampilan mengajar) guru akan meningkat. Hasil ini didukung dengan hasil penelitian Wasiso, (Wahyuningtyas \& Sulasmono, 2020) yang membandingkan hasil belajar siswa dalam mata pelajaran sejarah antara guru yang mengajar dengan menggunakan model pembelajaran dengan guru yang mengajar dengan cara konvensional menemukan bahwa terdapat perbedaan hasil belajar sejarah antara siswa yang belajar dengan model pembelajaran Two StayTwo Stray (TSTS) dan konvensional. Kemudian (Kasmiatun, 2020) yang meneliti pembelajaran menggunakan model discovery learning dengan media puzzle menunjukkan bahwa prosentase nilai rata-rata minat belajar siswa menjadi 89\%. Lalu (Habibbulloh \& Arifin, 2019) yang melakukan penelitian penerapan model pembelajaran tipe STAD berbantuan alat peraga Al-Quran mampu meningkatkan penguasaan tajwid hukum nun sukun dan tanwin siswa kelas IV SD. Dan hasil penelitian (Yamah, 2021) yang melakukan penelitian tentang efektifitas Model Pembelajaran Kooperatif Tipe STAD dalam mengatasi kesulitan siswa memahami konsep Ekonomi Pokok Bahasan Ketenagakerjaan, ternyata menghasilkan hasil penelitian bahwa model pembelajaran koperatif tipe STAD dapat meningkatkan kemampuan pemahaman siswa yang ditinjau dari hasil belajar. Tentunya hasil belajar siswa yang meningkat disebabkan keterampilan mengajar guru yang meningkat atau semakin baik dengan menggunakan model pembelajaran.

Dengan demikian dapat dianalisa bahwa pembimbingan keterampilan guru dalam menerapkan model pembelajaran berarti memberikan bekal kemampuan guru untuk dapat lebih optimal dalam mengelola pembelajaran sehingga pencapaian tujuan pembelajaran dapat lebih optimal pula. Dalam diri setiap peserta didik terdapat potensi kognitif (pengetahuan), potensi psikomotorik (keterampilan) dan potensi afektif (moral). Hal ini sesuai dengan yang dijelaskan (Sudjana, 2013) yang telah membagi kompetensi guru kepada 
Journal Continuous Education

Volume 2, Issue 3, November 2021

Page 1-15

1) kompetensi bidang kognitif artinya kemampuan intelektual seperti penguasaan mata pelajaran, pengetahuan mengenai cara mengajar, cara belajar dan tingkah laku individu, bimbingan penyuluhan, administrasi kelas, cara menilai hasil belajar siswa, tentang kemasyarakatan dan pengetahuan umum lainnya, 2) kompetensi bidang sikap artinya kesiapan dan kesediaan guru terhadap berbagai hal yang berkenaan dengan tugas dan profesinya, 3) kompetensi perilaku/performance artinya kemampuan guru dalam berbagai keterampilan berperilaku seperti keterampilan mengajar, membimbing, menilai, menggunakan alat bantu pengajaran, bergaul atau berkomunikasi dan lain sebagainya. Penambahan pengetahuan, wawasan dan keterampilan guru tentang hal yang sangat diperlukan mereka dalam menyajikan pembelajaran akan membuat keterampilan mengajar mereka bertambah. Jika keterampila mengajarnya meningkat maka pencapaian tujun pendidikan Nasional juga akan meningkat.

Kemudian pembimbingan untuk meningkatkan keterampilan mengajar guru disertai juga praktek mengajar oleh para guru. Dengan praktek mengajar maka para guru akan mengaplikasikan pengetahuan yang diperoleh saat bimbingan dalam unjuk kerjanya dengan mengajar. Pada praktek mengajar keterampilan mengajar para guru akan diamati dan dinilai oleh peserta pelatihan dan juga oleh pembimbing. Ternyata praktek mengajar guru saat bimbingan dalam penelitian ini, dapat meningkatkan keterampilan mengajar guru bidang studi Agama MTsN Pematangsiantar. Kegiatan melakukan pengamatan dan penilaian mengajar seperti ini sering dilakukan oleh pengawas melalui supervisi akademik. Pada supervisi akademik seorang pengawas (pembimbing) melakukan pengamatan dan penilaian terhadap performance (kemampuan) guru dalam menyajikan materi pembelajaran di lokal, mulai dari perencanaan pembelajaran sampai melakukan evaluasi dan umpan balik. Setelah melakukan supervisi akademik pengawas akan memberikan masukan untuk perbaikan bagi guru ke depannya. Ternyata kegiatan supervisi akademik ini juga telah berhasil meningkatkan keterampilan mengajar guru. Hasil penelitian ini sesuai dengan hasil penelitian (Lalupanda, 2019) menyatakan bahwa supervisi akademik menyebabkan terjadi peningkatan skor yang diperoleh guru pada asfek perencanaan dan pelaksanaan. Hal ini berarti supervisi akademik yang dilakukan kepala sekolah dapat meningkatkan mutu pembelajaran dan mutu guru. Kemudian hal ini juga sesuai dengan yang dikemukakan (Makawimbang, 2012) yang menyatakan bahwa tujuan supervisi adalah perbaikan dan perkembangan proses belajar mengajar secara total, pemberian bimbingan dan pembinaan dalam hal implentasi kurikulum, pemilihan dan penggunaan metode mengajar, 
Journal Continuous Education

Volume 2, Issue 3, November 2021

Page 1-15

alat-alat pelajaran, prosedur dan teknik evaluasi pengajaran, dan sebagainya. Kemudian supervisi akademik dapat meningkatkan keterampilan mengajar juga sesuai dengan penelitian (Wahono \& Jabar, 2016) yang menyatakan bahwa supervisi akademik dapat meningkatkan keterampilan mengajar guru. Juga hal ini diperkuat oleh (Karsiyem \& Wangid, 2015) yang hasil penelitiannya menunjukkan bahwa unsur supervisi yang meliputi perencanaan, pelaksanaan, dan penilaian pembelajaran ternyata dapat meningkatkan mutu guru dalam mengajar.

\section{KESIMPULAN}

Berdasarkan uraian dan paparan di atas dapat disimpulkan sebagai berikut :

1. Pembimbingan dan praktek mengajar yang dilakukan terhadap guru MTsN Pematangsiantar telah berhasil meningkatkan keterampilan mengajar mereka.

2. Nilai rata-rata keterampilan mengajar guru pada Prasiklus sebesar 112,00 dan nilai rata-rata keterampilan mengajar guru pada Siklus I meningkat menjadi sebesar 220,47 kemudian nilai rata-rata keterampilan mengajar guru pada Siklus II mengalami peningkatan menjadi sebesar 253,40. Dengan demikian pembimbingan dan praktek mengajar yang diberikan kepada para guru berhasil meningkatkan keterampilan mengajarnya.

3. Secara keseluruhan hasil evaluasi terhadap kegiatan pembimbingan dan praktek mengajar yang dilakukan dalam penelitian ini telah cukup baik serta perlu dilakukan dengan lebih baik lagi untuk masa yang akan datang sehingga mendapatkan hasil yang lebih baik dan bermanfaat untuk kemajuan pendidikan.

\section{DAFTAR PUSTAKA}

Amri, A., Arsyad, A., Usman, S., \& Bunyamin, A. (2019). Principal's Leadership In Improving The Quality Of Education In Athirah Islamic Senior High School Makassar. International Journal Of Social Sciences, 79(1).

Ananda, R., \& Abdillah. (2018). Pembelajaran Terpadu. Karakteristik, Landasan, Fungsi, Prinsip Dan Model, Medan. Lembaga Peduli Pengembangan Pendidikan Indonesia (LPPPI).

Bafadal, I. (2008). Peningkatan Profesionalisme Guru Sekolah Dasar. Bumi Aksara. Darwamawan, D. (2013). Metode Penelitian Kuantitafif. Rosdakarya.

Ekasari, W. N. P. (2015). Pengaruh Kompetensi Pedagogik Terhadap Kemampuan Guru Dalam Mengelola Kegiatan Pembelajaran IPS di SMP Negeri Kota Singaraja. Jurnal Jurusan Pendidikan Ekonomi, 5(1).

Habibbulloh, M., \& Arifin, A. (2019). The Efektivitas Model Pembelajaran Kooperatif Stad Menggunakan Alat Peraga Alquran Untuk Meningkatkan 
Journal Continuous Education

Volume 2, Issue 3, November 2021

Page 1-15

Penguasaan Tajwid. Jurnal Pendidikan Agama Islam, 16(2), 189-202. https:// doi.org/10.14421/jpai.2019.162-04

Karsiyem, K., \& Wangid, M. N. (2015). Pelaksanaan Supervisi Akademik Dalam Peningkatan Kinerja Guru Sekolah Dasar Gugus Iii Sentolo Kulon Progo. Jurnal Akuntabilitas Manajemen Pendidikan, 3(2), 201-212. https://doi.org/10.21831/amp.v3i2.6337

Kasmiatun, K. (2020). Upaya meningkatkan minat belajar pelajaran seni budaya melalui model discovery learning dengan media puzzle. Jurnal Penelitian Ilmu Pendidikan, 13(1), 52-62. https:/ / doi.org/10.21831/jpipfip.v13i1.29984

Kristiawan, M., \& Rahmat, N. (2018). Peningkatan Profesionalisme Guru Melalui Inovasi Pembelajaran. Jurnal Iqra' : Kajian Ilmu Pendidikan, 3(2), 373390.

https://journal.iaimnumetrolampung.ac.id/index.php/ji/article/view/34 $8 / 267$

Lalupanda, E. M. (2019). Implementasi supervisi akademik untuk meningkatkan mutu guru. Jurnal Akuntabilitas Manajemen Pendidikan, 7(1), 62-72. https:/ / doi.org/10.21831/amp.v7i1.22276

Lexy Moleong. (2014). Metodologi Penelitian Kualitatif. PT Remaja Rosdakarya. Makawimbang, J. H. (2012). Kepemimpinan Pendidikan yang Bermutu. Alfabeta.

Mustofa, M. (2018). Efektivitas Pelatihan Program Mahasiswa Bidang TIK Dalam Meningkatkan Kompetensi Calon Guru PAI (Studi di Fakultas Ilmu Tarbiyah dan Keguruan UIN Sunan Kalijaga). Jurnal Pendidikan Agama Islam, 15(2), 36-47. https:// doi.org/10.14421/jpai.2018.152-03

Piet, S. (2009). Konsep Dasar dan Teknik Supervisi Pendidikan Edisi Revisi. Remaja Rosdakarya.

Sholikhah, E., Rohman, A., Hanum, F., Efianingrum, A., \& Sukardi, J. S. (2019). Children's intelligence development training for Aisyiyah kindergarten teachers. Jurnal Penelitian Ilmu Pendidikan, 12(2), 129-138. https://doi.org/10.21831/jpipfip.v12i2.26920

Sudarwan, D. (2012). Pengembangan Profesi Guru Dari Pra-Jabatan, Induksi ke Profesional Madani. Alfabeta.

Sudjana, N. (2013). Penilaian Hasil Proses Belajar Mengajar. Remaja Rosdakarya.

Sugiyono. (2016). Metode Penelilitian Kuantitatif, Kualitatif dan RED. Alfabeta.

Sugiyono. (2020). Metode Penelitian Pendidikan. Alfabeta.

Wahono, S. B., \& Jabar, C. S. A. (2016). Keefektifan Supervisi Akademik Kepala SMK Negeri Kelompok Teknologi Dan Rekayasa Di Kabupaten Kebumen. Jurnal Akuntabilitas Manajemen Pendidikan, 4(2), 270. https://doi.org/10.21831/amp.v4i2.10808

Wahyuningtyas, R., \& Sulasmono, B. S. (2020). Pentingnya Media dalam Pembelajaran Guna Meningkatkan Hasil Belajar di Sekolah Dasar. EDUKATIF : Jurnal Ilmu Pendidikan.

https://doi.org/10.31004/edukatif.v2i1.77

Wardhana, R. A. nandi. (2016). Pengaruh Kepemimpinan Kepala Sekolah, Profesionalisme Dan Pelatihan Guru Terhadap Implementasi Kurikulum 2013 SMKN Yogyakarta. Jurnal Akuntabilitas Manajemen Pendidikan, 4(2), 
257. https:/ / doi.org/10.21831/amp.v4i2.10812

Wina Sanjaya. (2007). Education Strategy Oriented Education Process Standards. Kencana.

Yamah. (2021). Efektifitas Model Pembelajaran Kooperatif Tipe STAD Dalam Mengatasi Kesulitan Siswa Memahami Konsep Ekonomi Pokok Bahasan Ketenagakerjaan. Jurnal Al-Hikmah, https://ejournal.uniks.ac.id/index.php/Alhikmah/article/view/1135

Zaini, M. F. (2019). The Implementation Of Learning Management In Class VIII Madrasa Tsanawiyah Islamiyah (MTS) YPI Batangkuis. International Conference on Islamic Educational Management (ICIEM). https:/ / scholar.google.co.id/citations?user=9xE516oAAAAJ\&hl=id\#d=gs_ md_cita-

$\mathrm{d} \& \mathrm{u}=\%$ 2Fcitations \%3Fview_op\%3Dview_citation \%26hl\%3Did \%26user\%3 D9xE516oAAAAJ\%26citation_for_view\%3D9xE516oAAAAJ\%3Au5HHmV D_uO8C\%26tzom\%3D-420

Zaini, M. F., \& Syafaruddin, S. (2020). The Leadership Behavior of Madrasah Principals in Improving the Quality of Education in MAN 3 Medan. Jurnal Iqra': Kajian Ilmu Pendidikan, 5(2), 95-106. https://doi.org/10.25217/ji.v5i2.649 